\title{
CACNA1B (Ca 2.2$)$ Overexpression and Its Association with Clinicopathologic Characteristics and Unfavorable Prognosis in Non-Small Cell Lung Cancer
}

\author{
Xiaoyu Zhou, ${ }^{1,2}$ Wei Wang, ${ }^{3}$ Shu Zhang, ${ }^{3}$ Xudong Wang, ${ }^{4}$ Zhiyuan Tang, \\ Jun Gu, ${ }^{1,2}$ Jun Li, ${ }^{1,2}$ and Jianan Huang ${ }^{1}$ \\ ${ }^{1}$ Department of Respiratory Medicine, The First Affiliated Hospital of Soochow University, Suzhou, China \\ ${ }^{2}$ Department of Respiratory Medicine, Affiliated Hospital of Nantong University, Nantong, Jiangsu 226001, China \\ ${ }^{3}$ Department of Pathology, Affiliated Hospital of Nantong University, Nantong, Jiangsu 226001, China \\ ${ }^{4}$ Department of Laboratory Medicine, Affiliated Hospital of Nantong University, Nantong, Jiangsu 226001, China \\ Correspondence should be addressed to Jianan Huang; huangiianannt@126.com
}

Received 13 July 2016; Revised 5 September 2016; Accepted 8 September 2016; Published 3 January 2017

Academic Editor: Stamatios E. Theocharis

Copyright (C) 2017 Xiaoyu Zhou et al. This is an open access article distributed under the Creative Commons Attribution License, which permits unrestricted use, distribution, and reproduction in any medium, provided the original work is properly cited.

\begin{abstract}
CACNA1B $\left(\mathrm{Ca}_{\mathrm{v}} 2.2\right)$ encodes an N-type voltage-gated calcium channel (VGCC) ubiquitously expressed in brain and peripheral nervous system that is important for regulating neuropathic pain. Because intracellular calcium concentration is a key player in cell proliferation and apoptosis, VGCCs are implicated in tumorigenesis. Recent studies have identified CACNA1B (Ca 2.2$)$ being overexpressed in prostate and breast cancer tissues when compared to adjacent normal tissues; however, its role in nonsmall cell lung cancer (NSCLC) has not been investigated. In this study, we determined the mRNA and protein expression of CACNA1B $\left(\mathrm{Ca}_{\mathrm{v}} 2.2\right)$ in NSCLC tumorous and adjacent nontumorous tissues by quantitative reverse transcription PCR (qRTPCR) and tissue microarray immunohistochemistry analysis (TMA-IHC), respectively. CACNA1B $\left(\mathrm{Ca}_{\mathrm{v}} 2.2\right)$ protein expressions in tumorous tissues were correlated with NSCLC patients' clinical characteristics and overall survival. CACNA1B $\left(\mathrm{Ca}_{\mathrm{v}} 2.2\right) \mathrm{mRNA}$ and protein expression levels were higher in NSCLC tumorous tissues than in nontumorous tissues. High CACNA1B $\left(\mathrm{Ca}_{\mathrm{v}} 2.2\right)$ protein expression was associated with higher TNM stages, and CACNA1B $\left(\mathrm{Ca}_{\mathrm{v}} 2.2\right)$ protein expression is an independent prognostic marker in NSCLC. Based on our results, we conclude that CACNA1B $\left(\mathrm{Ca}_{\mathrm{v}} 2.2\right)$ plays a role in NSCLC development and progression. Elucidating the underlying mechanism may help design novel treatment by specifically targeting the calcium regulation pathway for NSCLC, a devastating disease with increasing incidence and mortality in China.
\end{abstract}

\section{Introduction}

Primary lung cancer remains the leading cause of cancer death worldwide and in China [1-3]. It is estimated that 605,900 patients were diagnosed and 486,600 patients died of lung cancer in 2010 in China [4, 5]. Lung cancer incidence and mortality are higher in men and urban areas than those in women and rural areas, and it is estimated that air pollution will replace smoking as the primary cause of lung cancer in China by 2020 [4]. Non-small cell lung cancer (NSCLC) accounts for over $80 \%$ of these lung cancer cases and includes the following histologic types: adenocarcinoma, squamous cell carcinoma, large cell carcinoma, and mixed histologies [6,7]. About a quarter to a third of NSCLC patients are diagnosed with stage I or II disease, which allows surgical resection with curative intent [8]. However, despite a complete and presumably curative resection, approximately $40-50 \%$ of patients with resected NSCLC die of recurrent disease [9]. Molecular prognostic markers are needed to identify subset of patients that would benefit from aggressive treatment after surgical resection [10].

Calcium $\left(\mathrm{Ca}^{2+}\right)$ is a key mediator of signaling transduction pathways regulating cell cycle, cell proliferation, and cell death [11-13]. $\mathrm{Ca}^{2+}$ can regulate the activities of many intracellular enzymes including kinases and phosphatases, 
and slight variations in $\mathrm{Ca}^{2+}$ level and distribution could activate or inhibit specific cell functions, thus intracellular $\mathrm{Ca}^{2+}$ alteration is associated with several pathological conditions, including cancer [14]. A number of mechanisms are used to precisely regulate the intracellular $\mathrm{Ca}^{2+}$ concentration, including active transporting $\mathrm{Ca}^{2+}$ out of the cell, storing $\mathrm{Ca}^{2+}$ in the endoplasmic reticulum (ER).

The voltage-gated calcium channels (VGCCs) are main regulators of intracellular $\mathrm{Ca}^{2+}$ level. Overexpression of various VGCC members has been detected in various cancer types, including leukemia [15], breast [16], prostate [17], ovarian [18], and lung cancer [15]. CACNA1B $\left(\mathrm{Ca}_{\mathrm{v}} 2.2\right)$ is the only member in N-type VGCC family, and CACNAlB $\left(\mathrm{Ca}_{\mathrm{v}} 2.2\right)$ overexpression has been detected in breast and prostate cancer [15], and it represents a novel therapeutic target for the treatment of breast and prostate cancer. However, its role in NSCLC is unknown.

In the current study, we determined both mRNA and protein expression of CACNA1B $\left(\mathrm{Ca}_{\mathrm{v}} 2.2\right)$ in NSCLC tissue samples by quantitative reverse transcription PCR (qRTPCR) and tissue microarray immunohistochemistry analysis (TMA-IHC), respectively, and correlated to patients' clinical characteristics and overall survival.

\section{Material and Methods}

2.1. Human Tissue Specimens and Patient Clinical Information. A total of 164 NSCLC patients were included in the study. Twenty-four NSCLC patients consented and were enrolled before surgery, and 24 pairs matched tumorous and nontumorous fresh tissue samples were collected and frozen at the time of surgery. All samples in this study were from clinical biobank in Affiliated Hospital of Nantong University, Jiangsu Province, China. In addition, 140 NSCLC patients provided 140 pairs matched tumorous and nontumorous formalinfixed paraffin-embedded (FFPE) tissue blocks. Clinical characteristics were obtained from patients' medical records. In the current study, the normal control samples are defined as adjacent nontumorous tissue samples. The study protocol was approved by the Human Research Ethics Committee of the Affiliated Hospital of Nantong University, Jiangsu, China.

2.2. CACNA1B $\left(\mathrm{Ca}_{v}\right.$ 2.2) $m R N A$ and Protein Expression and Statistical Analysis. CACNA1B ( $\left.\mathrm{Ca}_{\mathrm{v}} 2.2\right)$ mRNA level was determined by quantitative reverse transcription PCR (qRTPCR) using relative quantification method by normalizing to the housekeeping gene GAPDH [19]. The primers used are as follows: CACNA1B $\left(\mathrm{Ca}_{\mathrm{v}} 2.2\right)$ forward primer $\left(5^{\prime}\right.$-AAC ATT CTG GAC TTC ATT-3') and CACNA1B $\left(\mathrm{Ca}_{\mathrm{v}} 2.2\right)$ reverse primer $\left(5^{\prime}\right.$-AGA GAC TTG ATG GTA TTG- $\left.3^{\prime}\right)$ and GAPDH forward primer $\left(5^{\prime}\right.$-TGC ACC ACC AAC TGC TTA GC-3') and GAPDH reverse primer $\left(5^{\prime}\right.$-GGC ATG GAC TGT GGT CAT GAG-3 $\left.3^{\prime}\right)$. CACNA1B $\left(\mathrm{Ca}_{\mathrm{v}} 2.2\right)$ protein expression in tissue blocks was determined using tissue microarray immunohistochemistry (TMA-IHC) [20]. Rabbit polyclonal anti-human CACNA1B $\left(\mathrm{Ca}_{\mathrm{v}} 2.2\right)$ antibody was used (dilution 1:500, ab121193, Abcam, USA). The CACNA1B ( $\left.\mathrm{Ca}_{\mathrm{v}} 2.2\right)$ IHC data were scored using the semiquantitative $\mathrm{H}$-score

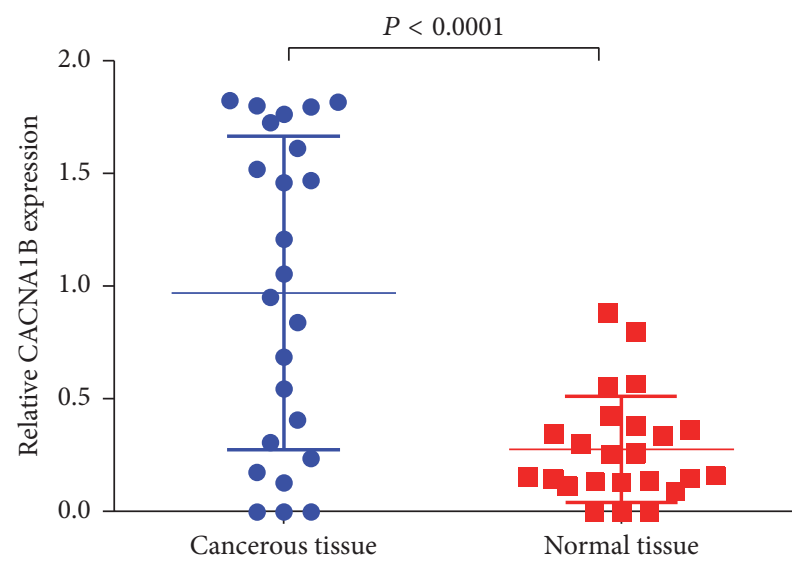

FIgURE 1: CACNA1B ( $\left.\mathrm{Ca}_{\mathrm{v}} 2.2\right)$ mRNA level was significantly higher in NSCLC tumorous tissues than in adjacent nontumorous tissues. CACNA1B $\left(\mathrm{Ca}_{\mathrm{v}} 2.2\right)$ mRNA was determined by qRT-PCR and relative quantification analysis by normalizing to GAPDH mRNA.

method taking into account both the staining intensity and the percentage of cells at that intensity [21], ranging from 0 to 300. Subsequently, the continuous CACNA1B $\left(\mathrm{Ca}_{\mathrm{v}} 2.2\right)$ protein expression data were converted into dichotic data (low versus high) using specific cutoff values, which were selected to be significant in terms of overall survival (OS) using the X-tile software program (The Rimm Lab at Yale University; http://medicine.yale.edu/lab/rimm/research/software.aspx) $[22,23]$. In the current study, the cutoff was 90 : score 0-90 was considered low expression while 100-300 was considered high expression.

Statistical analysis was performed as described before [24]. Student's $t$-test was used to compare CACNA1B $\left(\mathrm{Ca}_{\mathrm{v}} 2.2\right)$ mRNA and protein expression between tumorous and nontumorous tissue samples. Pearson $\chi^{2}$ tests were performed to determine the correlation between CACNA1B $\left(\mathrm{Ca}_{\mathrm{v}} 2.2\right)$ expression and clinicopathologic parameters. Univariate and multivariate Cox regression models were used to identify prognostic factors. Kaplan-Meier method was used to calculate survival curves. For all analyses, a $P$ value $<0.05$ was regarded as statistically significant. Data were analyzed using SPSS 20 statistics software (SPSS Inc., Chicago, IL, USA) and STATA 12.0 (StataCorp, College Station, TX, USA).

\section{Results}

3.1. CACNA1B ( $\left.\mathrm{Ca}_{v} 2.2\right)$ mRNA Level Was Significantly Higher in NSCLC Tumorous Tissues than in Adjacent Nontumorous Tissues. We determined CACNA1B ( $\left.\mathrm{Ca}_{\mathrm{v}} 2.2\right)$ mRNA level in 24 pairs of fresh frozen NSCLC tumorous and adjacent nontumorous tissues. Relative CACNA1B ( $\left.\mathrm{Ca}_{\mathrm{v}} 2.2\right)$ mRNA expression level was normalized to the expression of housekeeping gene GAPDH. CACNA1B $\left(\mathrm{Ca}_{\mathrm{v}} 2.2\right)$ mRNA expression level was significantly higher in NSCLC tumorous tissues $(0.97 \pm 0.14)$ when compared to adjacent nontumorous tissues $(0.28 \pm 0.05)(P<0.001)$ (Figure 1$)$. 
TABLE 1: Correlation of CACNA1B $\left(\mathrm{Ca}_{\mathrm{v}} 2.2\right)$ expression in tumor tissues with clinicopathologic characteristics in non-small cell lung cancer (NSCLC) patients.

\begin{tabular}{|c|c|c|c|c|c|}
\hline \multirow{2}{*}{ Clinicopathologic characteristics } & \multirow{2}{*}{$n$} & \multicolumn{4}{|c|}{ CACNA1B $\left(\mathrm{Ca}_{\mathrm{v}} 2.2\right)$} \\
\hline & & Low or no expression & High expression & Pearson $\chi^{2}$ & $P$ \\
\hline Total & 140 & $58(41.43)$ & $82(58.57)$ & 29.594 & $P<0.001^{*}$ \\
\hline \multicolumn{6}{|l|}{ Gender } \\
\hline Male & 69 & $22(31.88)$ & $47(68.12)$ & 5.108 & $0.018^{*}$ \\
\hline Female & 71 & $36(50.70)$ & $35(49.30)$ & & \\
\hline \multicolumn{6}{|l|}{ Age at diagnosis (years) } \\
\hline$\leq 60$ & 66 & $26(39.39)$ & $40(60.61)$ & 2.063 & 0.103 \\
\hline$>60$ & 74 & $32(43.24)$ & $42(56.76)$ & & \\
\hline \multicolumn{6}{|l|}{ Tumor size $(\mathrm{cm})$} \\
\hline$\leq 3$ & 75 & $40(53.33)$ & $35(46.67)$ & 9.435 & $0.002^{*}$ \\
\hline$>3$ & 65 & $18(27.69)$ & $47(72.31)$ & & \\
\hline \multicolumn{6}{|l|}{ Histopathology grading } \\
\hline Adenocarcinoma & 92 & $45(48.91)$ & $47(51.09)$ & 9.222 & $0.010^{*}$ \\
\hline Squamous cell carcinoma & 30 & $11(36.67)$ & $19(63.33)$ & & \\
\hline Others $^{\mathrm{a}}$ & 18 & $2(11.11)$ & $16(88.89)$ & & \\
\hline \multicolumn{6}{|l|}{ Lymph node metastasis } \\
\hline No regional lymph node metastasis & 98 & $49(50.00)$ & $49(50.00)$ & & \\
\hline Metastasis in ipsilateral peribronchial lymph nodes & 22 & $6(27.27)$ & $16(72.73)$ & 10.541 & $0.005^{*}$ \\
\hline Metastasis in mediastinal lymph nodes & 20 & $3(15.00)$ & $17(85.00)$ & & \\
\hline \multicolumn{6}{|l|}{ Smoking } \\
\hline Smoking & 20 & $4(20.00)$ & $16(80.00)$ & 4.415 & $0.029^{*}$ \\
\hline No smoking & 120 & $54(45.00)$ & $66(55.00)$ & & \\
\hline \multicolumn{6}{|l|}{ Stage grouping with TNM } \\
\hline Stage I & 21 & $8(38.10)$ & $13(61.90)$ & 1.730 & 0.421 \\
\hline Stage II & 46 & $16(34.78)$ & $30(65.22)$ & & \\
\hline Stage III & 73 & $34(46.58)$ & $39(53.42)$ & & \\
\hline
\end{tabular}

3.2. CACNA1B ( $\left.\mathrm{Ca}_{v} 2.2\right)$ Protein Level Was Significantly Higher in NSCLC Tumorous Tissues than in Adjacent Nontumorous Tissues. We determined CACNA1B $\left(\mathrm{Ca}_{\mathrm{v}} 2.2\right)$ protein expression in 140 pairs matched tumorous and adjacent nontumorous archived NSCLC tissue blocks. High CACNA1B $\left(\mathrm{Ca}_{\mathrm{v}} 2.2\right)$ expression was detected in $58.57 \%$ of tumorous tissues, with significantly higher than $41.43 \%$ detected in matched adjacent nontumorous tissues (Table 1, Pearson $\chi^{2}=29.594, P<$ 0.001). Typical IHC staining patterns for CACNA1B $\left(\mathrm{Ca}_{\mathrm{v}} 2.2\right)$ in NSCLC are shown in Figure 2.

3.3. Association of CACNA1B $\left(\mathrm{Ca}_{v} 2.2\right)$ Expression with NSCLC Clinical Characteristics. Next, we correlated CACNA1B $\left(\mathrm{Ca}_{\mathrm{v}} 2.2\right)$ protein expression with NSCLC patients' clinical characteristics, including gender, age at diagnosis, tumor size, histopathology grading, lymph node metastasis, smoking history, and TNM stage. High CACNA1B $\left(\mathrm{Ca}_{\mathrm{v}} 2.2\right)$ protein expression was significantly associated with gender (Pearson $\chi^{2}=5.108, P=0.018$ ), tumor size (Pearson $\chi^{2}=9.435$, $P=0.002$ ), histopathology grading (Pearson $\chi^{2}=9.222$, $P=0.010$ ), lymph node metastasis (Pearson $\chi^{2}=10.541$,
$P=0.005)$, and smoking (Pearson $\chi^{2}=4.415, P=0.029$ ) (Table 1).

3.4. High CACNA1B $\left(\mathrm{Ca}_{v} 2.2\right)$ Expression Predicts Poor Overall Survival in NSCLC Patients. Finally, we analyzed prognostic factors in NSCLC patients using both univariate and multivariate analyses. In univariate analysis, high CACNA1B $\left(\mathrm{Ca}_{\mathrm{v}} 2.2\right)$ expression (HR, 2.701, 95\% CI: 1.797-4.061; $P<$ 0.001), male (HR, 1.530, 95\% CI: 1.070-2.188; $P=0.020$ ), large tumor size $(3 \mathrm{~cm})(\mathrm{HR}, 2.064,95 \% \mathrm{CI}: 1.431-2.976$; $P<0.001$ ), high histopathology grading (HR, 0.419, 95\% CI: $0.306-0.574 ; P<0.001)$, lymph node metastasis (HR, 1.482, 95\% CI: 1.005-2.185; $P=0.047$ ), smoking (HR, 2.237, 95\% CI: $1.365-3.666 ; P=0.001)$, and advanced TNM stage (HR, 1.425, 95\% CI: 1.108-1.833; $P=0.006$ ) were significantly associated with overall survival. These significant factors were then included in the multivariate analysis. In multivariate analysis, high CACNA1B ( $\left.\mathrm{Ca}_{\mathrm{v}} 2.2\right)$ expression (HR, 2.639, 95\% CI: 1.699-4.099; $P<0.001)$, high histopathology grading (HR, 0.572, 95\% CI: 0.392-0.837; $P=0.004$ ), and smoking (HR, 2.526, 95\% CI: 1.440-4.430; $P=0.001$ ) remained 


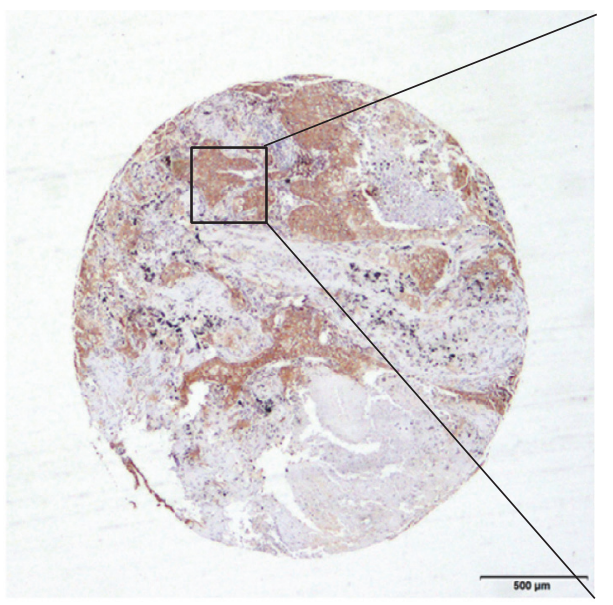

(a1)

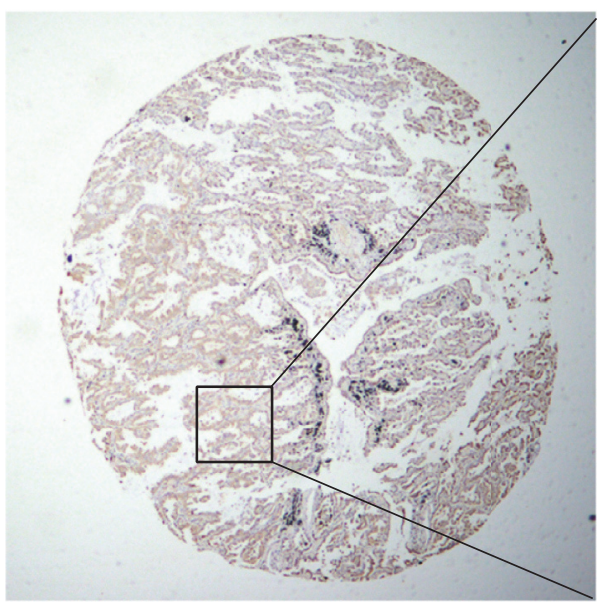

(b1)

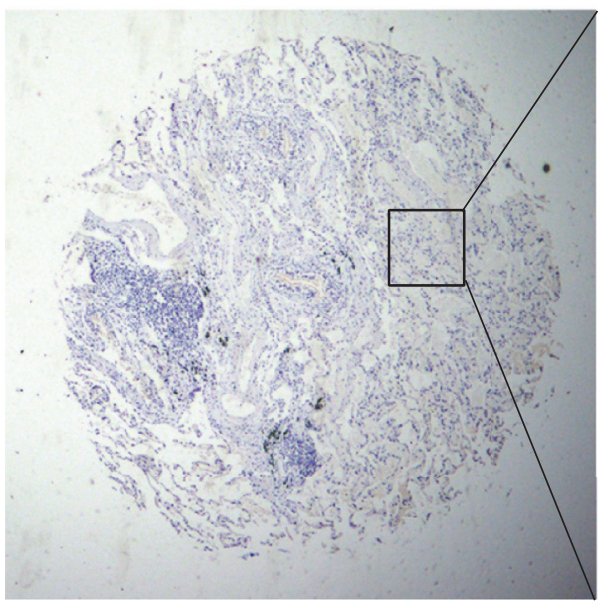

$(\mathrm{c} 1)$

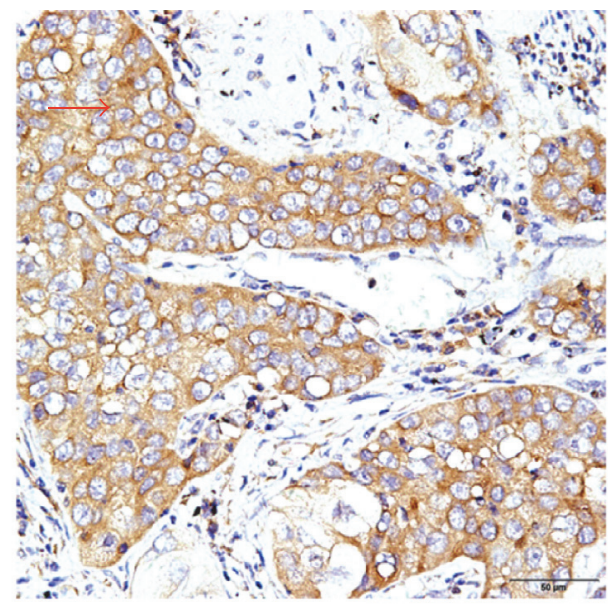

(a2)

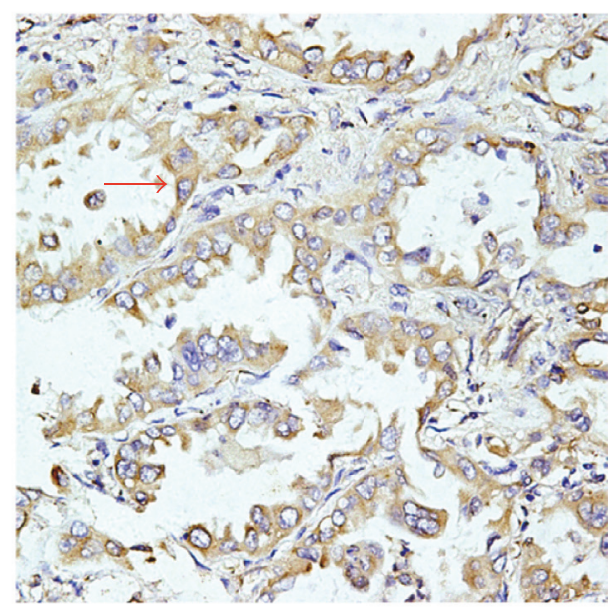

(b2)

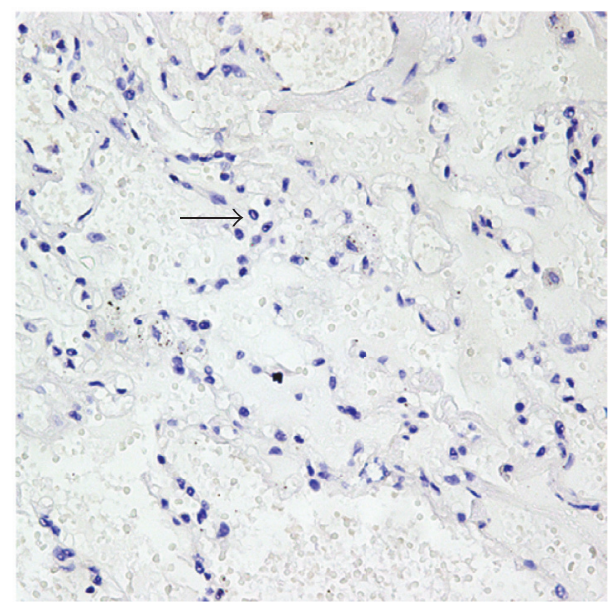

(c2)

FIGURE 2: Representative immunohistochemistry (IHC) images showing expression of CACNA1B (Ca 2.22$)$ in tissue microarray sections of NSCLC. (a1) and (a2) show strong positive staining in the cytoplasm of squamous cell carcinoma tissues. (b1) and (b2) show moderate positive staining in the cytoplasm of adenocarcinoma tissues. (c1) and (c2) show a negative IHC reaction in matched adjacent normal tissues. Original magnification was $\times 40$ for (a1) and (b1) and $\times 400$ for (a2) and (b2). 
TABLE 2: Univariate and multivariate analysis of prognostic factors in CACNA1B $\left(\mathrm{Ca}_{\mathrm{v}} 2.2\right)$ for 5 -year overall survival.

\begin{tabular}{|c|c|c|c|c|c|c|}
\hline \multirow{2}{*}{ Characteristic } & \multicolumn{3}{|c|}{ Univariate analysis } & \multicolumn{3}{|c|}{ Multivariate analysis } \\
\hline & HR & $P$ & $95 \% \mathrm{CI}$ & HR & $P$ & $95 \% \mathrm{CI}$ \\
\hline \multicolumn{7}{|l|}{ CACNA1B $\left(\mathrm{Ca}_{\mathrm{v}} 2.2\right)$ expression } \\
\hline High versus low & 2.701 & $<0.001$ & 1.7974 .061 & 2.639 & $<0.001^{*}$ & 1.6994 .099 \\
\hline \multicolumn{7}{|l|}{ Gender } \\
\hline Male versus female & 1.530 & 0.020 & 1.0702 .188 & 1.230 & 0.339 & 0.8041 .882 \\
\hline \multicolumn{7}{|l|}{ Age (years) } \\
\hline$\leq 60$ versus $>60$ & 1.273 & 0.189 & 0.8881 .826 & & & \\
\hline \multicolumn{7}{|l|}{ Tumor size $(\mathrm{cm})$} \\
\hline$\leq 3$ versus $>3$ & 2.064 & $<0.001$ & 1.4312 .976 & 1.138 & 0.597 & 0.7051 .836 \\
\hline \multicolumn{7}{|l|}{ Histopathology grading } \\
\hline Adenocarcinoma versus squamous cell carcinoma versus others ${ }^{\mathrm{a}}$ & 0.419 & $<0.001$ & 0.3060 .574 & 0.572 & $0.004^{*}$ & 0.3920 .837 \\
\hline \multicolumn{7}{|l|}{ Lymph node metastasis } \\
\hline No metastasis versus metastasis & 1.482 & 0.047 & 1.0052 .185 & 0.995 & 0.985 & 0.5751 .721 \\
\hline \multicolumn{7}{|l|}{ Smoking } \\
\hline No smoking versus smoking & 2.237 & 0.001 & 1.3653 .666 & 2.526 & $0.001^{*}$ & 1.4404 .430 \\
\hline \multicolumn{7}{|l|}{ TNM stage } \\
\hline Stage I versus stage II versus stage III & 1.425 & 0.006 & 1.1081 .833 & 1.349 & 0.147 & 0.9002 .024 \\
\hline
\end{tabular}

${ }^{*} P<0.05 ;{ }^{a}$ others, adenosquamous carcinoma.

significantly associated with poor overall survival (Table 2). Similar results were shown by the Kaplan-Meier survival curve (Figure 3).

\section{Discussion}

In the current study, we determined mRNA and protein expression levels of CACNA1B $\left(\mathrm{Ca}_{\mathrm{v}} 2.2\right)$ in both NSCLC tumorous and adjacent nontumorous tissues. CACNA1B $\left(\mathrm{Ca}_{\mathrm{v}} 2.2\right) \mathrm{mRNA}$ and protein level were significantly higher in tumorous tissues than in adjacent nontumorous tissues. High CACNA1B $\left(\mathrm{Ca}_{\mathrm{v}} 2.2\right)$ protein level was significantly associated with TNM staging. Finally, high CACNA1B $\left(\mathrm{Ca}_{\mathrm{v}} 2.2\right)$ protein expression is an independent prognostic marker for poor overall survival in NSCLC patients.

Calcium is a key second messenger that is involved in virtually every aspect of cellular function, including cell proliferation, apoptosis, gene transcription, and angiogenesis. In normal resting cells, the cytoplasmic $\mathrm{Ca}^{2+}$ level is maintained at $\sim 100 \mathrm{nM}$ significantly lower than extracellular $\mathrm{Ca}^{2+}$ concentration and $\mathrm{Ca}^{2+}$ concentration in endoplasmic reticulum (ER). There is increasing evidence suggesting that an increase of intracellular $\mathrm{Ca}^{2+}$ concentration leads to cell growth and proliferation, while the decrease of $\mathrm{ER} \mathrm{Ca}^{2+}$ concentration inhibits apoptosis $[14,25]$.

The precise control of intracellular free $\mathrm{Ca}^{2+}$ changes is essential for the proper regulation of many cellular pathways, including those important in tumorigenesis and cancer progression [14]. $\mathrm{Ca}^{2+}$ is a key regulator of cell cycle, thus cell proliferation [26]; excess accumulation of $\mathrm{Ca}^{2+}$ in mitochondria is linked to apoptosis and necrosis and reduction of $\mathrm{Ca}^{2+}$ in ER is associated with resistance to apoptosis [27-29]. For example, altered $\mathrm{ER} \mathrm{Ca}^{2+}$ level led to cisplatin and Taxol resistance in NSCLC cell lines [30, 31], and reduced ER $\mathrm{Ca}^{2+}$ is a protective mechanism for prostate cancer cells escaping cell death in the absence of androgenic stimulation [32]. In addition, extracellular $\mathrm{Ca}^{2+}$ signaling is implicated in differentiation [33]; $\mathrm{Ca}^{2+}$ regulates cellular motility, thus implicated in tumor invasion and metastasis [34-36]; $\mathrm{Ca}^{2+}$ is a key regulator of angiogenesis signaling pathway [37]; $\mathrm{Ca}^{2+}$ regulates gene transcription [28] and DNA damage response pathway [38]; finally, $\mathrm{Ca}^{2+}$ is involved in the regulation of telomerase activity [39].

Voltage-gated calcium channels (VGCCs) are main regulators of intracellular $\mathrm{Ca}^{2+}$ homeostasis. There are five types of family members including L, N, T, R, and P/Q types, and their involvement in carcinogenesis has been investigated in both clinical correlational studies and in vitro functional studies. For example, clinical studies have demonstrated overexpression of CACNA1D $\left(\mathrm{Ca}_{\mathrm{v}} 1.3\right)$ (L type), CACNA1A $\left(\mathrm{Ca}_{\mathrm{v}} 2.1\right)$ (P/Q type), and CACNA1G $\left(\mathrm{Ca}_{\mathrm{v}} 3.1\right)$ (T type) in lung cancer, and overexpression of CACNA1A $\left(\mathrm{Ca}_{\mathrm{v}} 2.1\right)$ was associated with poor prognosis [15]. Mechanistically, colon cancer cells treated with calcium channel agonist induced apoptosis [40], and overexpression of CACNA2D2 in lung cancer cell lines induced apoptosis through elevating intracellular $\mathrm{Ca}^{2+}$ level $[41,42]$.

CACNA1B $\left(\mathrm{Ca}_{\mathrm{v}} 2.2\right)$ is an N-type VGCC and expressed in the brain and the peripheral nervous system. Previous study has linked CACNA1B $\left(\mathrm{Ca}_{\mathrm{v}} 2.2\right)$ to neuropathic pain $[43,44]$ and CACNA1B $\left(\mathrm{Ca}_{\mathrm{v}} 2.2\right)$ mutation $(\mathrm{R} 1389 \mathrm{H})$ has been linked to myoclonus-dystonia syndrome, a rare movement disorder [45]. Very little is known about its role in carcinogenesis, except overexpression of CACNA1B $\left(\mathrm{Ca}_{\mathrm{v}} 2.2\right)$ was detected in both prostate and breast cancer [15]. Our data suggest that CACNA1B $\left(\mathrm{Ca}_{\mathrm{v}} 2.2\right)$ is overexpressed in NSCLC tumorous 


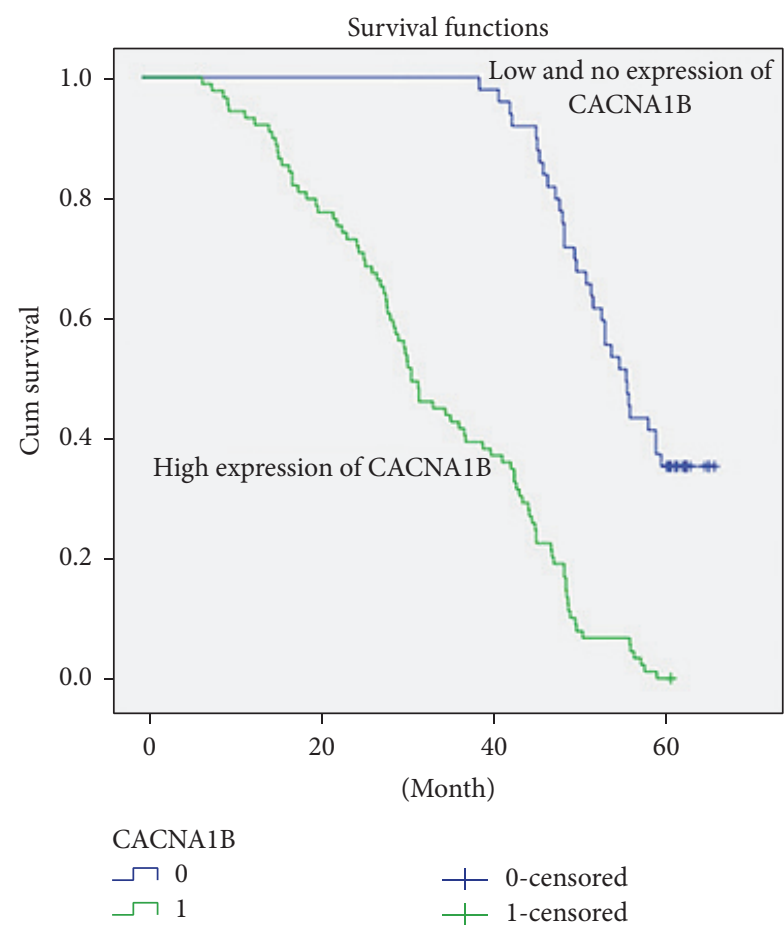

(a)

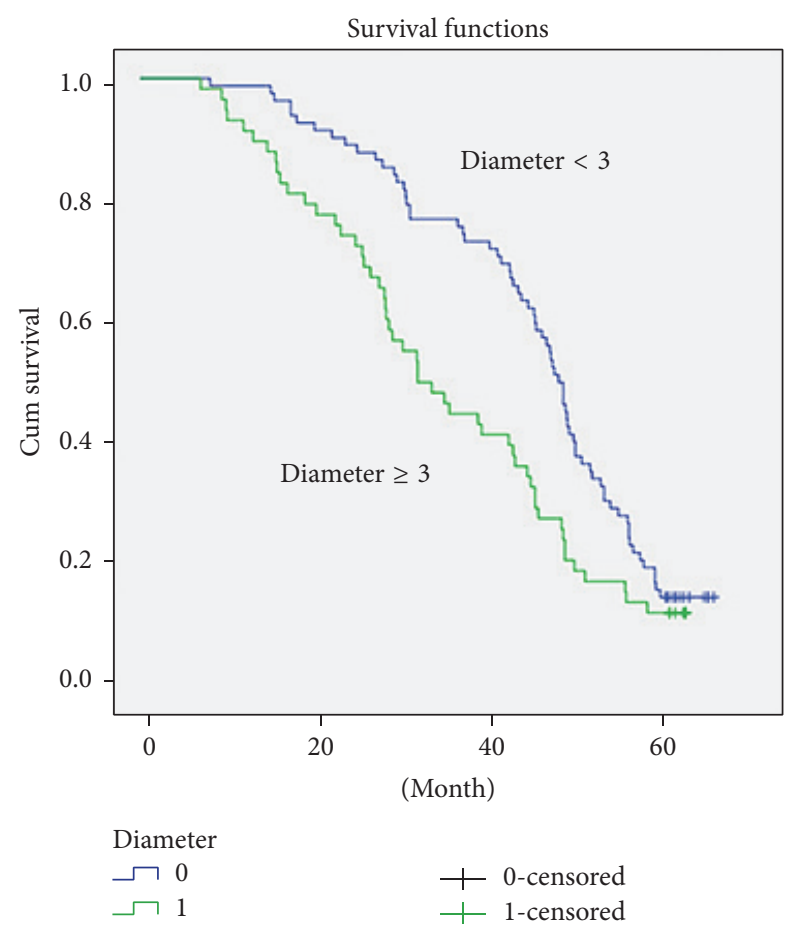

(b)

FIGURE 3: Survival curves of NSCLC patients by the Kaplan-Meier method and the log-rank test. (a) NSCLC patients with high CACNA1B $\left(\mathrm{Ca}_{\mathrm{v}} 2.2\right)$ expression (green line, 1$)$ had significantly worse overall survival than NSCLC patients with low or no CACNA1B $\left(\right.$ Ca $\left.a_{\mathrm{v}} 2.2\right)$ expression (blue line, 0); (b) NSCLC patients with larger tumor $(3 \mathrm{~cm}$ ) (green line, 1) had significantly worse overall survival than NSCLC patients with smaller tumor $(<3 \mathrm{~cm})$ (blue line, 0$)$.

tissues when compared to adjacent nontumorous tissues, and CACNA1B $\left(\mathrm{Ca}_{\mathrm{v}} 2.2\right)$ overexpression is also an independent prognostic marker for NSCLC. Future in vitro mechanistic studies are needed to determine whether CACNA1B $\left(\mathrm{Ca}_{\mathrm{v}} 2.2\right)$ regulates cell proliferation, apoptosis, or chemoresistance in lung cancer cells and whether CACNA1B $\left(\mathrm{Ca}_{\mathrm{v}} 2.2\right)$ influences the intracellular or $\mathrm{ER} \mathrm{Ca}^{2+}$ levels.

Our study has several limitations. First, our study is retrospective and subject to sample selection bias, so our conclusions could not be directly extended to other populations without further validation. Second, our sample size is small so we were unable to perform the analysis by cancer histological types. Third, we did not provide a mechanism for the role of CACNA1B $\left(\mathrm{Ca}_{\mathrm{v}} 2.2\right)$ in tumor development. It is unknown whether CACNA1B $\left(\mathrm{Ca}_{\mathrm{v}} 2.2\right)$ expression is associated with alterations in intracellular $\mathrm{Ca}^{2+}$ concentration. Future in vitro studies are needed to elucidate the underlying molecular mechanism.

\section{Conclusions}

In conclusion, our study demonstrates that CACNA1B $\left(\mathrm{Ca}_{\mathrm{v}} 2.2\right)$ plays a role in the development of NSCLC and CACNA1B $\left(\mathrm{Ca}_{\mathrm{v}} 2.2\right)$ overexpression is an independent prognostic marker for NSCLC in Chinese population. The function of CACNA1B $\left(\mathrm{Ca}_{v} 2.2\right)$ is tightly linked to tumor intracellular $\mathrm{Ca}^{2+}$ concentration; targeting intracellular calcium level through VGCCs might represent a novel therapy for NSCLC.

\section{Abbreviations}

NSCLC: Non-small cell lung cancer

VGCC: Voltage-gated calcium channel

qRT-PCR: Quantitative reverse transcription polymerase chain reaction

TMA-IHC: Tissue microarray immunohistochemistry analysis

TNM: $\quad$ Tumor node metastasis

ER: $\quad$ Endoplasmic reticulum

FFPE: $\quad$ Formalin-fixed paraffin-embedded

OS: Overall survival

HR: Hazard ratio.

\section{Competing Interests}

All the authors declare no competing financial interests.

\section{Acknowledgments}

The authors thank the clinical biobank members in Affiliated Hospital of Nantong University. This work was supported by grants from the National Natural Science Foundation of China (31270940 to Jianan Huang), Jiangsu Provincial Special Program of Medical Science (BL2012023), Clinical Medical Center of Suzhou and Clinical Key Speciality Project of China, and Key Technology Research of Nantong - People's Livelihood [MS22015114]. 


\section{References}

[1] Q.-Y. Hong, G.-M. Wu, G.-S. Qian et al., "Prevention and management of lung cancer in China," Cancer, vol. 121, supplement 17, pp. 3080-3088, 2015.

[2] C. Zhou, "Lung cancer molecular epidemiology in China: recent trends," Translational Lung Cancer Research, vol. 3, no. 5, pp. 270-279, 2014.

[3] J. Ferlay, I. Soerjomataram, R. Dikshit et al., "Cancer incidence and mortality worldwide: sources, methods and major patterns in GLOBOCAN 2012," International Journal of Cancer, vol. 136, no. 5, pp. E359-E386, 2015.

[4] W. Chen, R. Zheng, H. Zeng, and S. Zhang, "Epidemiology of lung cancer in China," Thoracic Cancer, vol. 6, no. 2, pp. 209215, 2015.

[5] R. Zheng, H. Zeng, T. Zuo et al., "Lung cancer incidence and mortality in China, 2011," Thoracic Cancer, vol. 7, no. 1, pp. 9499, 2016.

[6] G. Antonelli, M. Libra, V. Panebianco et al., "Molecular-targeted therapy for elderly patients with advanced non-small cell lung cancer," Oncology Letters, vol. 11, no. 1, pp. 3-8, 2016.

[7] C. Ho, K. M. Tong, K. Ramsden, D. N. Ionescu, and J. Laskin, "Histologic classification of non-small-cell lung cancer over time: reducing the rates of not-otherwise-specified," Current Oncology, vol. 22, no. 3, pp. e164-e170, 2015.

[8] P. McElnay and E. Lim, "Adjuvant or neoadjuvant chemotherapy for NSCLC," Journal of Thoracic Disease, vol. 6, no. 2, pp. S224-S227, 2014.

[9] S. K. Padda, B. M. Burt, N. Trakul, and H. A. Wakelee, "Early-stage non-small cell lung cancer: surgery, stereotactic radiosurgery, and individualized adjuvant therapy," Seminars in Oncology, vol. 41, no. 1, pp. 40-56, 2014.

[10] M. Burotto, A. Thomas, D. Subramaniam, G. Giaccone, and A. Rajan, "Biomarkers in early-stage non-small-cell lung cancer: current concepts and future directions," Journal of Thoracic Oncology, vol. 9, no. 11, pp. 1609-1617, 2014.

[11] E. Carafoli and J. Krebs, "Why calcium? How calcium became the best communicator," Journal of Biological Chemistry, vol. 291, no. 40, pp. 20849-20857, 2016.

[12] M. D. Mark, J. C. Schwitalla, M. Groemmke, and S. Herlitze, "Keeping our calcium in balance to maintain our balance," Biochemical and Biophysical Research Communications, 2016.

[13] D. E. Clapham, "Calcium signaling," Cell, vol. 131, no. 6, pp. 1047-1058, 2007.

[14] G. R. Monteith, D. McAndrew, H. M. Faddy, and S. J. RobertsThomson, "Calcium and cancer: targeting Ca2+ transport," Nature Reviews Cancer, vol. 7, no. 7, pp. 519-530, 2007.

[15] C.-Y. Wang, M.-D. Lai, N. N. Phan, Z. Sun, and Y.-C. Lin, "Meta-analysis of public microarray datasets reveals voltagegated calcium gene signatures in clinical cancer patients," PLOS ONE, vol. 10, no. 7, Article ID e0125766, 2015.

[16] I. Azimi, S. J. Roberts-Thomson, and G. R. Monteith, "Calcium influx pathways in breast cancer: opportunities for pharmacological intervention," British Journal of Pharmacology, vol. 171, no. 4, pp. 945-960, 2014.

[17] K. R. Loughlin, "Calcium channel blockers and prostate cancer," Urologic Oncology, vol. 32, no. 5, pp. 537-538, 2014.

[18] L. Zhuang, J.-B. Peng, L. Tou et al., "Calcium-selective ion channel, CaT1, is apically localized in gastrointestinal tract epithelia and is aberrantly expressed in human malignancies," Laboratory Investigation, vol. 82, no. 12, pp. 1755-1764, 2002.
[19] H.-J. Zhang, D.-F. Yao, M. Yao et al., "Annexin A2 silencing inhibits invasion, migration, and tumorigenic potential of hepatoma cells," World Journal of Gastroenterology, vol. 19, no. 24, pp. 3792-3801, 2013.

[20] Q. Wang, Q. Ni, X. Wang, H. Zhu, Z. Wang, and J. Huang, "High expression of RAB27A and TP53 in pancreatic cancer predicts poor survival," Medical Oncology, vol. 32, no. 1, p. 372, 2015.

[21] S. Detre, G. Saccani Jotti, and M. Dowsett, "A 'quickscore' method for immunohistochemical semiquantitation: Validation for oestrogen receptor in breast carcinomas," Journal of Clinical Pathology, vol. 48, no. 9, pp. 876-878, 1995.

[22] J. Huang, X. Fan, X. Wang et al., "High ROR2 expression in tumor cells and stroma is correlated with poor prognosis in pancreatic ductal adenocarcinoma," Scientific Reports, vol. 5, Article ID 12991, 2015.

[23] C. Lu, X. Wang, H. Zhu, J. Feng, S. Ni, and J. Huang, "Overexpression of ROR2 and Wnt5a cooperatively correlates with unfavorable prognosis in patients with non-small cell lung cancer," Oncotarget, vol. 6, no. 28, pp. 24912-24921, 2015.

[24] H. Zhang, M. Yao, W. Wu et al., "Up-regulation of annexin A2 expression predicates advanced clinicopathological features and poor prognosis in hepatocellular carcinoma," Tumor Biology, vol. 36, no. 12, pp. 9373-9383, 2015.

[25] H. Yang, Q. Zhang, J. He, and W. Lu, "Regulation of calcium signaling in lung cancer," Journal of Thoracic Disease, vol. 2, no. 1, pp. 52-56, 2010.

[26] P. J. Cullen and P. J. Lockyer, "Integration of calcium and Ras signalling," Nature Reviews Molecular Cell Biology, vol. 3, no. 5, pp. 339-348, 2002.

[27] P. Pinton and R. Rizzuto, "Bcl-2 and $\mathrm{Ca} 2+$ homeostasis in the endoplasmic reticulum," Cell Death and Differentiation, vol. 13, no. 8, pp. 1409-1418, 2006.

[28] R. Rizzuto and T. Pozzan, "Microdomains of intracellular $\mathrm{Ca}^{2+}$ : molecular determinants and functional consequences," Physiological Reviews, vol. 86, no. 1, pp. 369-408, 2006.

[29] R. Rizzuto, P. Pinton, D. Ferrari et al., "Calcium and apoptosis: facts and hypotheses," Oncogene, vol. 22, no. 53, pp. 8619-8627, 2003.

[30] S. Padar, C. van Breemen, D. W. Thomas, J. A. Uchizono, J. C. Livesey, and R. Rahimian, "Differential regulation of calcium homeostasis in adenocarcinoma cell line A549 and its Taxolresistant subclone," British Journal of Pharmacology, vol. 142, no. 2, pp. 305-316, 2004.

[31] K. Schrödl, H. Oelmez, M. Edelmann, R. M. Huber, and A. Bergner, "Altered Ca2-homeostasis of cisplatin-treated and low level resistant non-small-cell and small-cell lung cancer cells," Cellular Oncology, vol. 31, no. 4, pp. 301-315, 2009.

[32] B. Boutin, N. Tajeddine, G. Monaco et al., "Endoplasmic reticulum $\mathrm{Ca}(2+)$ content decrease by PKA-dependent hyperphosphorylation of type 1 IP3 receptor contributes to prostate cancer cell resistance to androgen deprivation," Cell Calcium, vol. 57, no. 4, pp. 312-320, 2015.

[33] D. D. Bikle, Y. Oda, and Z. Xie, "Calcium and 1,25(OH)2D: interacting drivers of epidermal differentiation," Journal of Steroid Biochemistry and Molecular Biology, vol. 89-90, pp. 355360, 2004.

[34] J.-B. Huang, A. L. Kindzelskii, A. J. Clark, and H. R. Petty, "Identification of channels promoting calcium spikes and waves in HT1080 tumor cells: their apparent roles in cell motility and invasion," Cancer Research, vol. 64, no. 7, pp. 2482-2489, 2004. 
[35] G. Amuthan, G. Biswas, H. K. Ananadatheerthavarada, C. Vijayasarathy, H. M. Shephard, and N. G. Avadhani, "Mitochondrial stress-induced calcium signaling, phenotypic changes and invasive behavior in human lung carcinoma A549 cells," Oncogene, vol. 21, no. 51, pp. 7839-7849, 2002.

[36] B. T. Jacques-Fricke, Y. Seow, P. A. Gottlieb, F. Sachs, and T. M. Gomez, " $\mathrm{Ca}^{2+}$ influx through mechanosensitive channels inhibits neurite outgrowth in opposition to other influx pathways and release from intracellular stores," The Journal of Neuroscience, vol. 26, no. 21, pp. 5656-5664, 2006.

[37] A. M. Patton, J. Kassis, H. Doong, and E. C. Kohn, "Calcium as a molecular target in angiogenesis," Current Pharmaceutical Design, vol. 9, no. 7, pp. 543-551, 2003.

[38] M. S. Bentle, K. E. Reinicke, E. A. Bey, D. R. Spitz, and D. A. Boothman, "Calcium-dependent modulation of poly(ADPribose) polymerase-1 alters cellular metabolism and DNA repair," Journal of Biological Chemistry, vol. 281, no. 44, pp. 33684-33696, 2006.

[39] S. Rosenberger, I. S. Thorey, S. Werner, and P. Boukamp, "A novel regulator of telomerase: S100A8 mediates differentiationdependent and calcium-induced inhibition of telomerase activity in the human epidermal keratinocyte line HaCaT," Journal of Biological Chemistry, vol. 282, no. 9, pp. 6126-6135, 2007.

[40] A. Zawadzki, Q. Liu, Y. Wang, A. Melander, B. Jeppsson, and H. Thorlacius, "Verapamil inhibits L-type calcium channel mediated apoptosis in human colon cancer cells," Diseases of the Colon and Rectum, vol. 51, no. 11, pp. 1696-1702, 2008.

[41] G. L. Carboni, B. Gao, M. Nishizaki et al., "CACNA2D2mediated apoptosis in NSCLC cells is associated with alterations of the intracellular calcium signaling and disruption of mitochondria membrane integrity," Oncogene, vol. 22, no. 4, pp. 615626, 2003.

[42] D. L. Carlisle, X. Liu, T. M. Hopkins, M. C. Swick, R. Dhir, and J. M. Siegfried, "Nicotine activates cell-signaling pathways through muscle-type and neuronal nicotinic acetylcholine receptors in non-small cell lung cancer cells," Pulmonary Pharmacology and Therapeutics, vol. 20, no. 6, pp. 629-641, 2007.

[43] T. Yamamoto and A. Takahara, "Recent updates of N-type calcium channel blockers with therapeutic potential for neuropathic pain and stroke," Current Topics in Medicinal Chemistry, vol. 9, no. 4, pp. 377-395, 2009.

[44] M. S. Lee, "Recent progress in the discovery and development of N-type calcium channel modulators for the treatment of pain," Progress in Medicinal Chemistry, vol. 53, pp. 147-186, 2014.

[45] J. L. Groen, A. Andrade, K. Ritz et al., "CACNA1B mutation is linked to unique myoclonus-dystonia syndrome," Human Molecular Genetics, vol. 24, no. 4, pp. 987-993, 2015. 


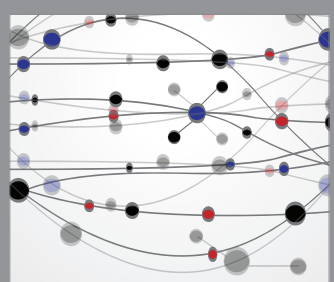

The Scientific World Journal
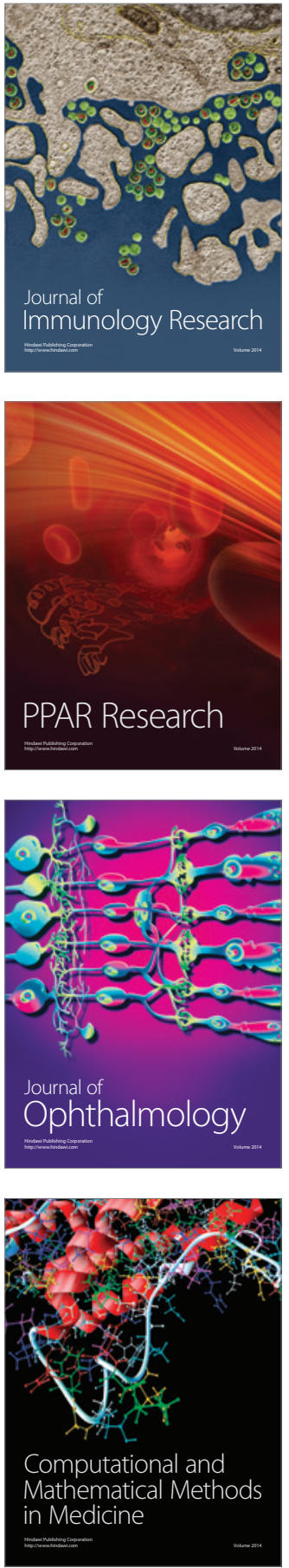

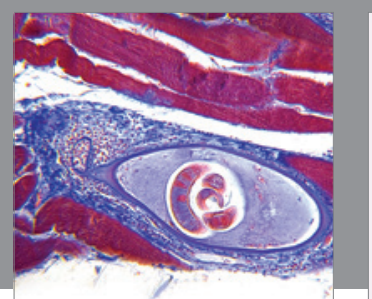

Gastroenterology Research and Practice
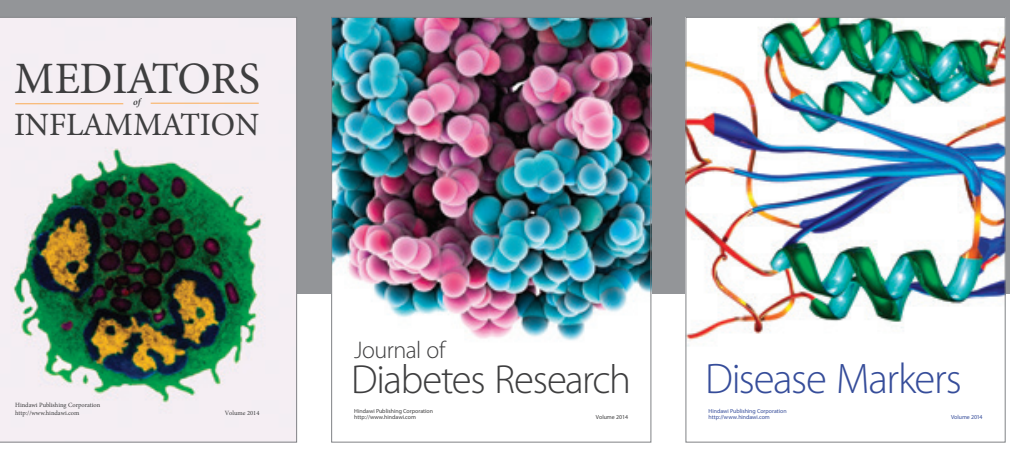

Disease Markers

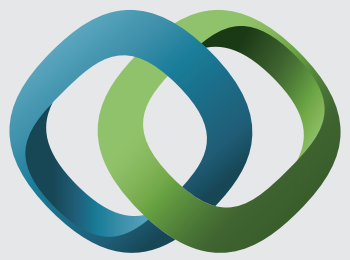

\section{Hindawi}

Submit your manuscripts at

https://www.hindawi.com
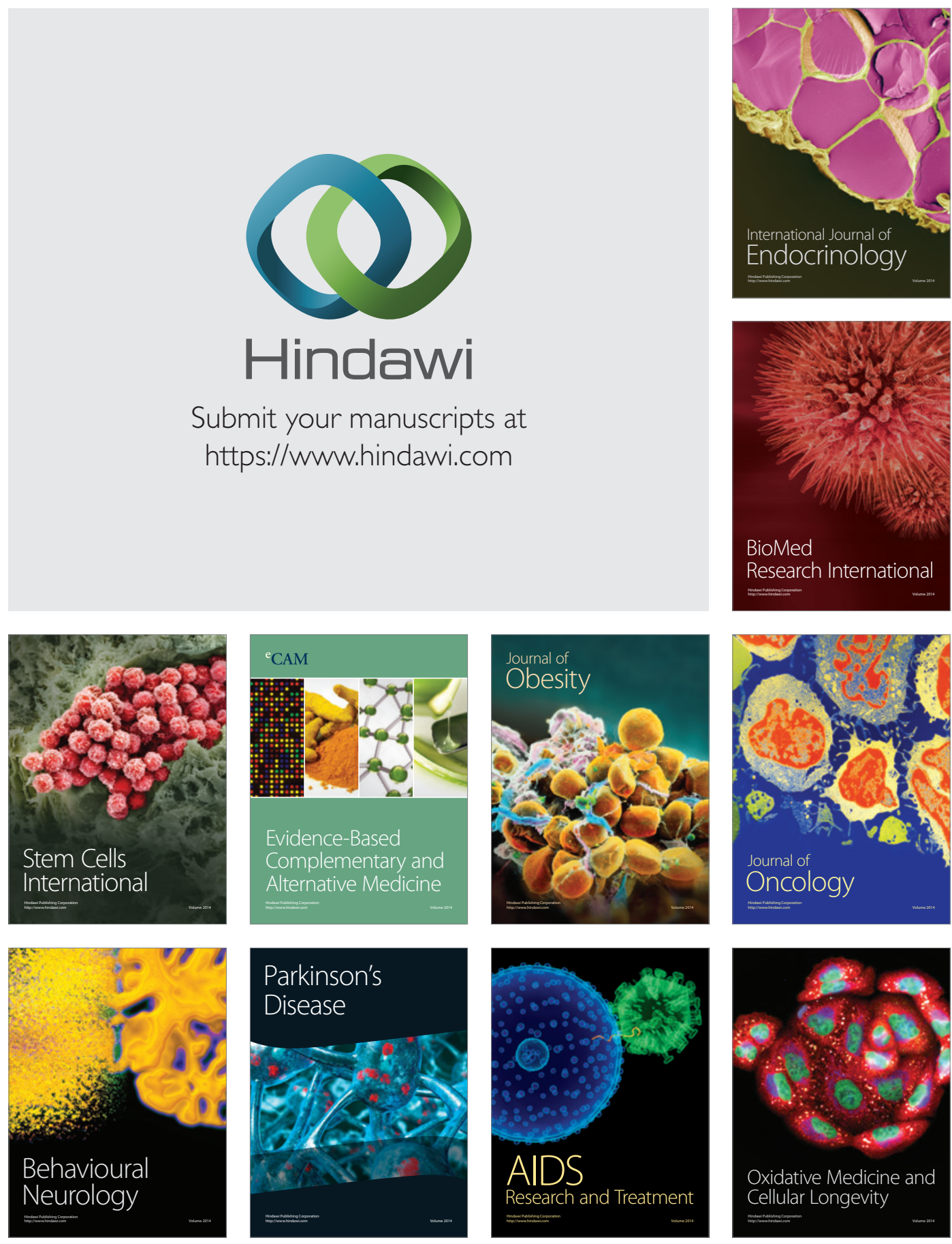